\title{
Is the distribution of the toxic dinoflagellate Alexandrium catenella expanding along the NW Mediterranean coast?
}

\author{
Magda Vila*, Esther Garcés, Mercedes Masó, Jordi Camp \\ Institut de Ciències del Mar, Passeig Marítim de la Barceloneta, 37-49, 08003 Barcelona, Catalonia, Spain
}

\begin{abstract}
The toxic dinoflagellate Alexandrium catenella is usually known as a cold waters species; however, during the summer of 1996 a bloom was observed in the Barcelona harbour (water temperatures above $20^{\circ} \mathrm{C}$ ). This was the first time that an $A$. catenella bloom occurred in Catalan waters. Recurrent blooms have been observed annually from 1996 to 1999 during the warm season in this harbour. Since its first detection A. catenella has been recorded at an increasing number of stations along the coast, suggesting a progressive areal expansion. Two toxic, widespread events of this species occurred in non-confined coastal waters along $100 \mathrm{~km}$ of coastline during the summers of 1998 and 1999. We argue that the newly constructed harbours, serving as confined habitats for the development and maintenance of $A$. catenella, have contributed to the expansion of the dinoflagellate on the NW Mediterranean coast.
\end{abstract}

KEY WORDS: Toxic dinoflagellate $\cdot$ Alexandrium catenella $\cdot$ NW Mediterranean Sea $\cdot$ Harmful algal blooms $\cdot$ HAB

Resale or republication not permitted without written consent of the publisher

\section{INTRODUCTION}

The global increase in toxic or harmful algal blooms (HABs) (Anderson et al. 1989, Smayda 1990, Hallegraeff 1993) has also included the NW Mediterranean, where numerous dinoflagellate blooms, especially involving the Alexandrium genus (A. minutum, A. tamarense and the non-toxic $A$. taylori) have been reported (Vila et al. 2001a). The potent neurotoxins (paralytic shellfish poisoning, PSP) produced by some Alexandrium species are accumulated by filter-feeding shellfish and other grazers and passed at higher trophic levels to humans, leading to illness, incapacitation, and even death (Anderson 1997). During the last few years, A. catenella, a potential PSP-producer, has been detected on the Catalan coast (NW Mediterranean Sea). This species has usually been reported in cold waters in several parts of the world, such as the west coast of

*E-mail: magda@icm.csic.es
North America from California to Alaska, southern and central Chile, and southern Argentina. It has also been observed in western South Africa, southern Australia (including Tasmania), the Kamchatka peninsula and Japan (Taylor 1984, Taylor et al. 1994, Balech 1995, Steidinger \& Tangen 1997). In the Mediterranean Sea, there were only a few references: A. catenella was listed as a rare species on a series of cruises across the Balearic basin (NW Mediterranean) (Margalef \& Estrada 1987). In 1994, it was detected in the Valencia harbour (NE Spanish coast) (Gomis et al. 1996), and it has also been found in net samples from the Tunis lagoon (S. Fraga pers. comm.). But A. catenella had never been observed either at monitoring stations along the Catalan coast from 1991 to 1995 or in the bays of the Ebro delta since 1989 (Delgado et al. 1998, 1999). A. catenella is commonly considered a coldwater organism, and so blooms in the Mediterranean Sea were not expected. But in spring 1998, the first widespread PSP toxic event caused by A. catenella was detected in the Mediterranean, and the phenome- 
non occurred again, although with less intensity, the next year (Vila et al. 2001b).

The rapid expansion of a toxic dinoflagellate, such as Alexandrium catenella, in the Mediterranean may have great environmental and health care consequences, and, thus, efforts directed to understand the mechanisms of such expansion are clearly needed. The aim of this paper is to report the rapid geographical expansion of $A$. catenella along the Catalan coast after its first detection in 1996. Increased distribution and abundance are discussed in relation to the possible causes that might have triggered its expansion, such as the trophic characteristics of the near-shore Catalan waters and the ability of dinoflagellates to colonise, settle and proliferate in confined habitats created or modified by human activity.

\section{METHODS}

Spatio-temporal distribution. Data presented in this paper were collected during the Monitoring of Harmful Algal Bloms Programme which operated on the Catalan coast (NW Mediterranean Sea) from July 1995 to December 1999 at 17 fixed stations. Of these stations, 14 were located in harbours, 1 at Cadaqués Bay, and 2 at beaches (Fig. 1A).

The sampling interval was once a week from May to October, and twice monthly from November to April, except for Les Cases harbour which was sampled weekly year-round. Surveillance was increased when potentially harmful phytoplankton was detected at the monitored stations. Additional samples for phytoplankton quantification were then collected from harbours, at beaches and breakwaters at neighbouring localities.

Salinity and temperature have been measured since March 1996. Bucket phytoplankton samples (150 ml) were taken from the surface during the day at selected sites inside the harbours (the most confined areas), bays or beaches, and preserved with formaldehyde (1\% final concentration) or Lugol's iodine solution. An aliquot was settled for $24 \mathrm{~h}$ in $50 \mathrm{ml}$ counting chambers, and an appropriate area of the chamber was then scanned (Throndsen 1995) for phytoplankton enumeration at 100 to $400 \times$ magnification using a Leica-Leitz DM-IL inverted
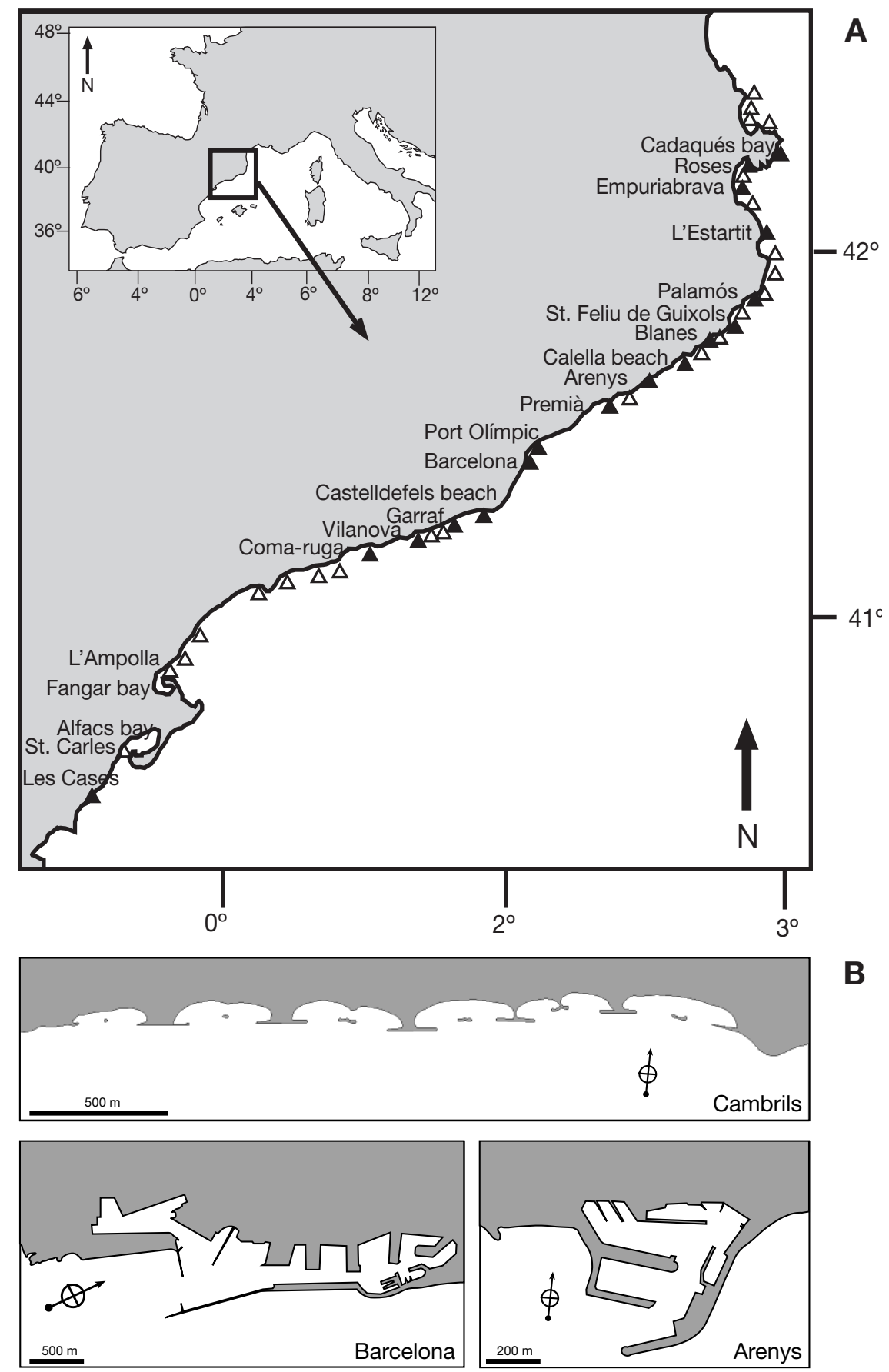

Fig. 1. (A) Study area along the Spanish coast showing the sampled stations (filled triangles) in the Monitoring of Harmful Algal Blooms Programme. Open triangles indicate non-sampled harbour locations. (B) Some examples of manmade confined waters: semi-enclosed beaches in Cambrils and 2 problematic HAB harbours (Barcelona, Arenys) 
microscope. About 30 cells were measured (length and width) with an image analysis system (Scion Image V1.62) attached to a Nikon Diaphot TMD microscope.

Small samples of Alexandrium catenella blooms were pipetted from the chambers and placed on microscope slides for taxonomical purposes. One drop of sodium hypochlorite was added to separate the thecal plates, and another drop of the fluorescent dye calcofluor white (Fritz \& Triemer 1985) was added to dye the plates. The slides were examined under $1000 \times$ magnification in the inverted microscope with fluorescent illumination.

Shellfish were collected for toxicity analysis when potentially toxic phytoplankton was detected during monitoring. Toxicity analysis was done following the standard mouse bioassay method (AOAC 1980). The permissible toxicity level in the European Union (EU) is $80 \mu \mathrm{g}$ saxitoxin-eq. (STX) per $100 \mathrm{~g}$ of mussel meat.

Surface water samples for nutrient analysis were collected at approximately $1 \mathrm{~m}$ depth and immediately frozen. Nutrients were determined automatically as described in Grasshoff et al. (1983). Nutrient samples come from an extensive environmental monitoring programme that includes 61 beaches and 11 harbours sampled during 3 and 2 annual cycles respectively. However the stations sampled for nutrients were not exactly the same as those sampled for phytoplankton.

Background and study area. Catalonia (NE Spain; $42^{\circ} 5^{\prime}$ to $40^{\circ} 5^{\prime} \mathrm{N}, 0^{\circ} 2^{\prime}$ to $3^{\circ} 2^{\prime} \mathrm{E}$ ) is situated on the NW Mediterranean Sea. Its coast extends along $400 \mathrm{~km}$ and is highly populated in some areas. On the central coast the human density is between 500 and 1300 inhabitants $\mathrm{km}^{-2}$ and reaches to up to 15000 inhabitants $\mathrm{km}^{-2}$ in the Barcelona area. In addition, total population increases by $>50 \%$ in some coastal regions during the tourist season. The recreational use of this coast has led to a demand for calm waters (breakwaters, semi-enclosed beaches) and an increase of recreational harbours (40 harbours on $400 \mathrm{~km}$ of coast, which, on average, represents 1 harbour for every $10 \mathrm{~km}$ of coastline). As a result $1 / 4$ of the Catalan coastline is characterised by man-made structures (Fig. 1B). On a topographic map (scale 1:50000) we measured $217 \mathrm{~km}$ of these man-made structures on a coastal length of $826 \mathrm{~km}$. The proportion of man-made coastal structures increased from $20 \%$ in the 1980 s to $27 \%$ in the 1990s (Institut Cartogàfic de Catalunya).

A phytoplankton monitoring programme has been in effect in the area since 1989, with weekly frequency at the Ebro delta bays, the only shellfish culture site on the Catalan coast; the rest of the coast was sporadically monitored (once every 2 to $3 \mathrm{mo}$ ) in non-confined waters from 1991 to 1994 . However, since 1995 a new Monitoring of Harmful Algal Blooms Programme has been established; the frequency of sampling and distri- bution of monitored stations along the coast have been substantially increased and based on a new concept focused on the sampling of confined waters. The unquestionable validity of this strategy in the detection and follow-up of the increase of HABs is discussed in Vila et al. (2001b).

Along the Catalan coast, water circulation is dominated by an along-shore north-southwest flow, associated with a shelf-slope front located approximately above the shelf-break region and characterised by mean velocities on the order of $20 \mathrm{~cm} \mathrm{~s}^{-1}$ (Font et al. 1988). The shelf region is characterised by a weak southward flow, with strong spatial and temporal variability and with the presence of local and intense saline or thermal fronts (Masó \& Duarte 1989, Masó \& Tintoré 1991). Trophic conditions such as concentrations of inorganic nutrients and their stoichiometric relationships in the near-shore coastal Catalan waters during summer months (June to September) are summarised in Table 1. We divided the area into 3 regions, the northern region, the central area, which is affected by Alexandrium catenella, and the southern area. The data indicate that the highest frequency of stoichiometric nutrient limitation is due to silicate limitation, but this is particularly so in the central area, where $>50 \%$ of the cases are potentially affected by silicate limitation. This central area is characterised by a high human density and consequently higher levels of $\mathrm{N}-\mathrm{NH}_{4}$ and $\mathrm{PO}_{4}$. If we consider the criteria of probable nutrient limitation (Justic et al. 1995), the frequencies (\%) of limitation of the 3 single nutrients decrease (probable silicate limitation being the highest, and similar in the 3 areas, about $25 \%$ ).

\section{RESULTS}

\section{The organism}

Given that Alexandrium catenella is commonly considered a cold-water species (Balech 1995), we document with microphotographs the organism observed in our study area, for taxonomic comparison (Fig. 2). Cells are small to medium-sized, 22.9 to $32.0 \mu \mathrm{m}$ long and 25.8 to $32.1 \mu \mathrm{m}$ wide (mean: $27 \mu \mathrm{m}$ long; $29 \mu \mathrm{m}$ wide). Although isolated cells are frequent, this species can form chains (commonly 4 cells per chain, but 2 to 8 have also been observed). Cells are flattened anteriorposteriorly when in chains, although single cells are sometimes isodiametric in shape. When dyed with calcofluor and observed under blue-excitation, plates can be seen (Fig. 2B). The triangular apical plate (Po) shows a connecting pore located near the comma head to its right (Fig. 2C). Plate 1 ' is directly connected to Po. The anterior right margin of $1^{\prime}$ is usually concave, but 


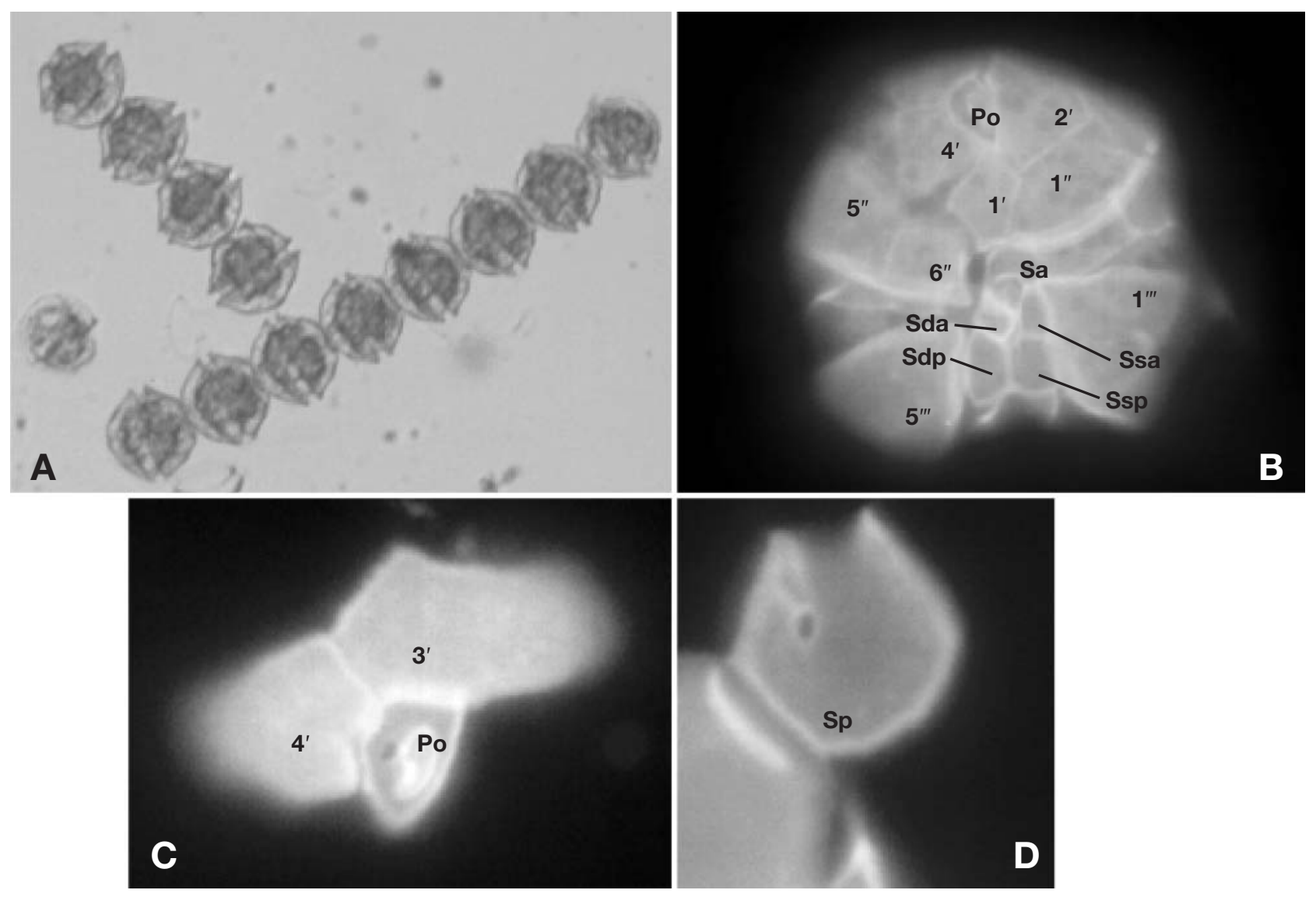

Fig. 2. Alexandrium catenella. Light microscope (LM) microphotographs of plankton samples. (A) LM of 4- and 8-celled chain. (B) LM (fluorescence) of cell, ventral view showing the plates. Calcofluor-stained. (C) LM (fluorescence) of details of a triangular apical pore plate (Po) with anterior attachment pore. (D) LM (fluorescence) of details of a posterior sulcal plate (Sp) with posterior attachment pore. The names of thecal plates are indicated by numbers, inverted commas, and letters. S indicates the 'sulcal plates'. Sa: anterior sulcal plate; Sda: right anterior lateral sulcal plate; Sdp: right posterior lateral sulcal plate; Ssp: left posterior lateral sulcal plate

it does not have a ventral pore. Plate $6 "$ is of medium width. The sulcal plate (Sp, Fig. 2D) is almost as wide as it is long, and presents a connecting pore to the right of the plate. Both pores (in Po and Sp plates) are transitory characteristics associated with chain formation.

\section{Large-scale distribution pattern along Catalan coast over 4 yr}

Alexandrium catenella was first detected in the Barcelona harbour in summer 1996. Since then it has increasingly been detected at the routinely monitored stations along the south-central coast, usually in higher concentrations year after year (Fig. 3).

Alexandrium catenella appears simultaneously at several stations every year, i.e. in 1997 at the beginning of July, in 1998 in late May, in 1999 in mid- to late June (Fig. 3). In the Barcelona harbour blooms lasted several months and attained high densities $\left(10^{5}\right.$ to $10^{7}$ cells $\left.1^{-1}\right)$.
However, at many stations (Garraf, Olímpic, Premià, Arenys and Calella) the population never reached high densities $\left(<10^{4}\right.$ cells $\left.\mathrm{l}^{-1}\right)$, and cells were present only during a few sampling occasions, often discontinuously. In the summers of 1998 and 1999, the maximum cell concentration occurred during the same week at several stations. In 1998, the maximum cell concentration was observed at the end of May at the southernmost stations (Coma-ruga, Vilanova) and at the beginning of July in the northern stations. In 1999, maximum cell concentration was observed at the end of June at all stations. Bloom terminations coincided at several stations in mid-September, except in 1999 when some cells were observed in mid-October.

\section{Widespread blooms}

In the summers of 1998 and 1999, 2 widespread blooms of Alexandrium catenella were also observed in 


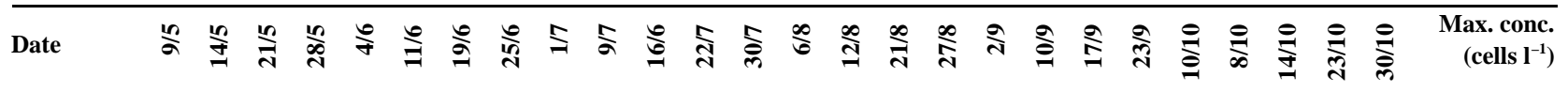

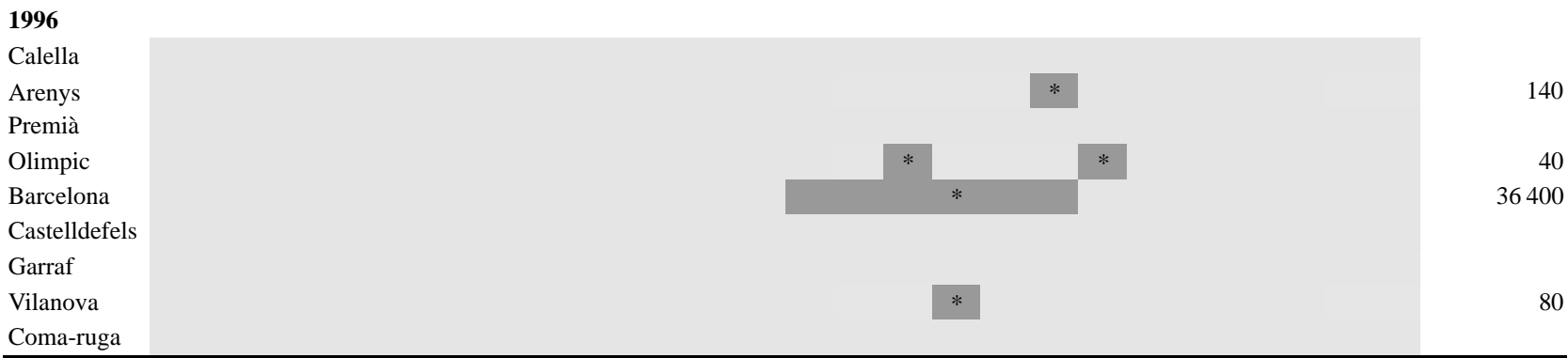

1997

Calella

Arenys

Premià

Olimplic

Barcelona

Castelldefels

Garraf

Vilanova

Coma-ruga

\section{8}

Calella

Arenys

Premià

Olimpic

Barcelona

Castelldefels

Garraf

Vilanova

Coma-ruga
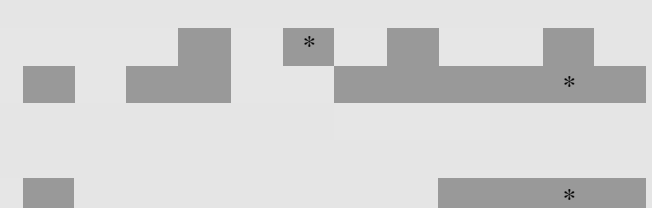

\section{9}

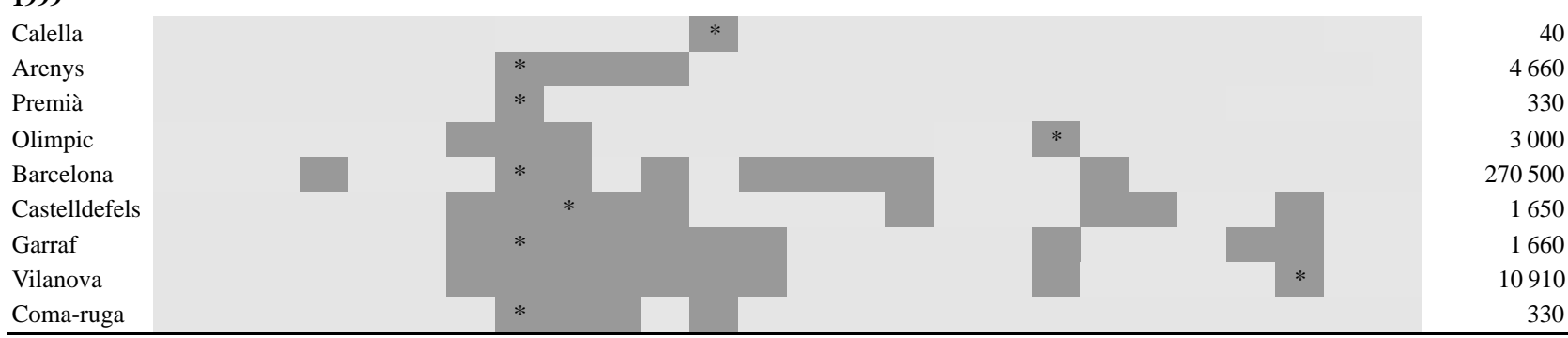

Fig. 3. Vegetative cell occurrence of Alexandrium catenella from 1996 through 1999, based on weekly samples during the warm months (May to October). Only the stations where the organism was present are shown. Note that 1995 is not shown because the species was not observed. Maximum cell concentration detected is given for each station; asterisk indicates the date of maximum concentration

non-confined waters (open beaches) and semi-enclosed beaches such as Cambrils (Fig. 1B). These blooms coincided with sunny days and calm weather, with surface water temperatures of 20 to $25^{\circ} \mathrm{C}$. Maximum cell concentrations and the areas affected are summarised in
Fig. 4. Maximum cell concentrations in non-confined waters were $10^{4}$ cells $\mathrm{l}^{-1}$. More than $10^{6}$ cells $\mathrm{l}^{-1}$ were

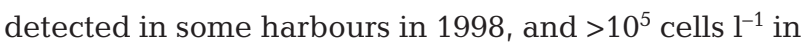
1999. In both 1998 and 1999, saxitoxin concentrations exceeded acceptable EU levels (AOAC 1980): up to 


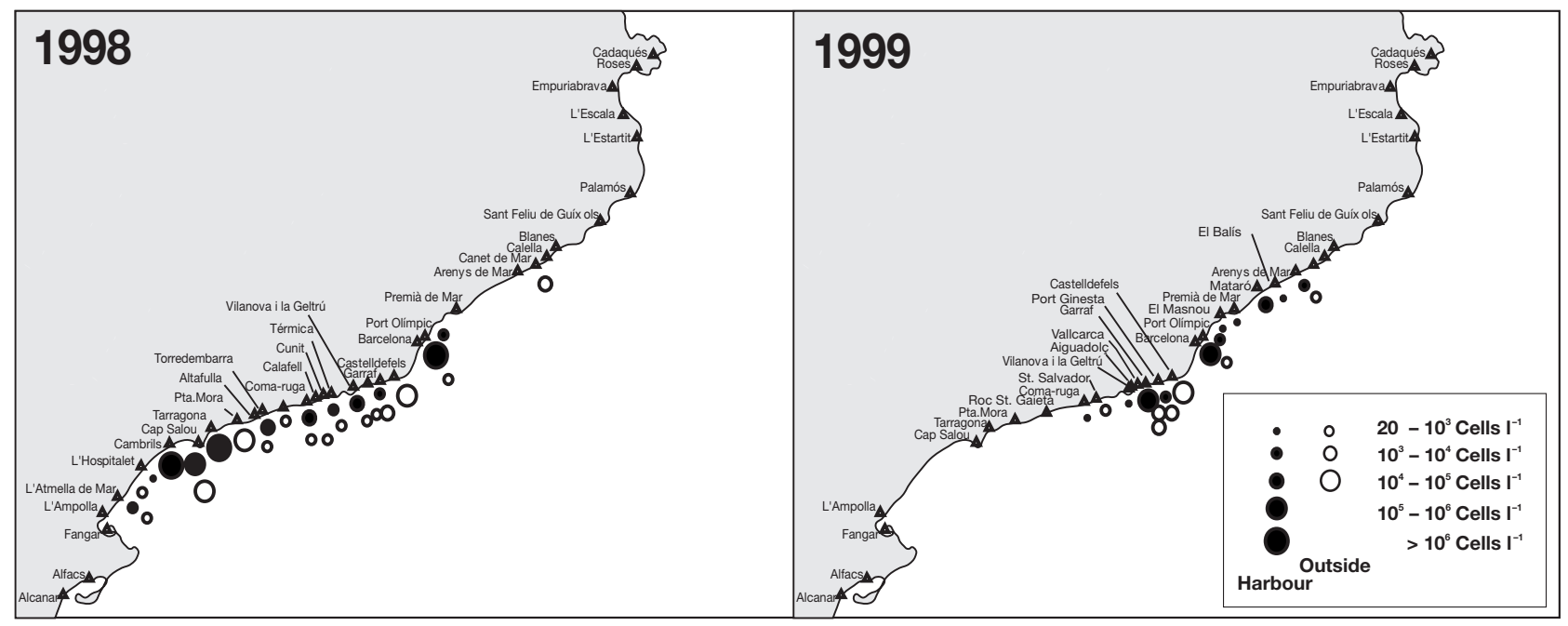

Fig. 4. Maximum coastal extension and concentration of Alexandrium catenella during the widespread blooms in summer 1998 and 1999 (closed symbols, cell concentration inside confined areas such as harbours or embayments; open symbols, cell concentration in non-confined waters; triangles, the location of stations monitored)

$983 \mu \mathrm{g}$ STX/100 g in 1998 and $150 \mu \mathrm{g}$ SXT/100 g in 1999. In 1999, bloom duration was shorter, and the maximum cell concentration and shellfish toxicity were lower than in 1998. However, in both years, A. catenella persisted in the confined waters for much longer (e.g. from July to mid-September in the Barcelona harbour) than in non-confined waters. The widespread blooms lasted for 8 wk in 1998 and 4 wk in 1999. cell densities in September coincided with the decrease in water temperature during this month. No cells were found after October. Temperature and A. catenella concentrations are weakly but significantly correlated ( $\mathrm{n}=36, \mathrm{r}=0.4$, Fig. 6) in this harbour. However, no significant correlation exists when we consider all the stations.

\section{Alexandrium catenella in Barcelona harbour}

A. catenella was first observed in Barcelona harbour during August through September 1996, reaching cell concentrations of up to 36400 cells $\mathrm{l}^{-1}$. Since then it has been observed every year in the harbour during the warm months (from May/June to September/October), achieving cell concentrations of up to $60 \times 10^{6}$ cells $1^{-1}$ (Fig. 5). Thus, A. catenella shows well-defined seasonality, with its vegetative cells detected only in water temperatures of 22 to $28^{\circ} \mathrm{C}$. In general, abundance increases suddenly, coinciding with the increase in water temperature (above $22^{\circ} \mathrm{C}$ ) that occurs in May to June. Maximum cell densities between $10^{5}$ and $10^{7}$ cells $1^{-1}$ were observed during July to August, coinciding with water temperatures above $24^{\circ} \mathrm{C}$. The decrease in

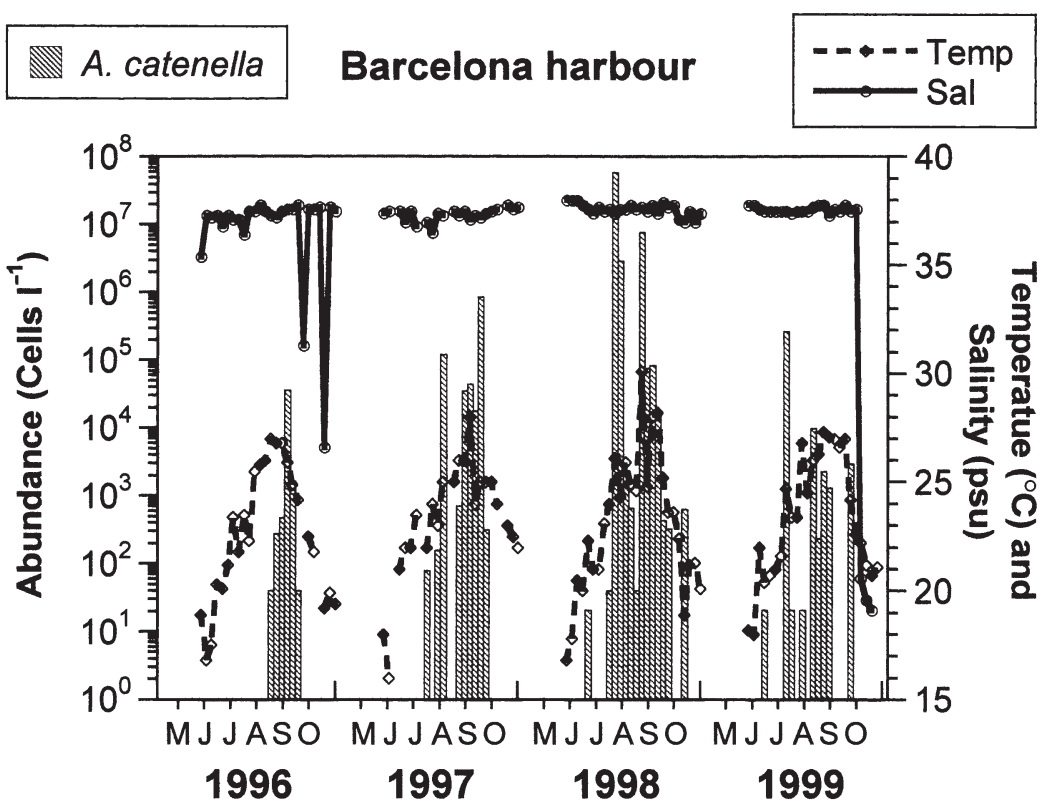

Fig. 5. Summer evolution (May to October) of cell density of Alexandrium catenella at the Barcelona harbour based on weekly samples (1996 to 1999) and associated temperature and salinity 


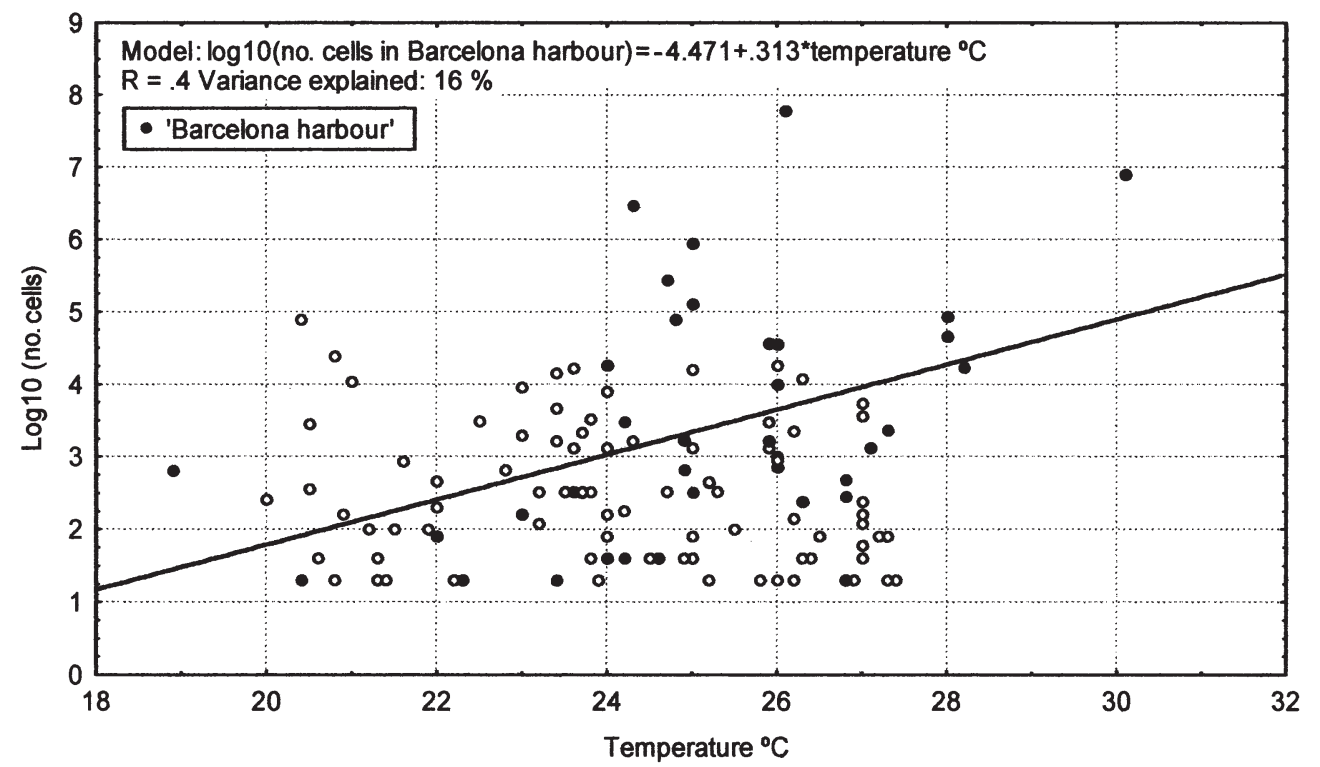

Fig. 6. Relationship between temperature and Alexandrium catenella concentrations in all the positive stations (closed symbols, Barcelona harbour data; open symbols data for remaining sites). A weak correlation exists when we consider only the Barcelona harbour data

\section{DISCUSSION}

Alexandrium catenella is considered to be a coldwater species that is seldom found at temperatures over $12^{\circ} \mathrm{C}$ and usually does not reproduce at above $16^{\circ} \mathrm{C}$ (Balech 1995). However, there are some reports that contradict the above assertions. It bloomed in Japanese waters (Tanaby Bay) during May 1981 and 1984 , reaching up to $3.5 \times 10^{6}$ cells $1^{-1}$, with water temperatures between $19.8^{\circ} \mathrm{C}$ and $21.5^{\circ} \mathrm{C}$ (Takeuchi et al. 1990, Takeuchi 1994). Furthermore, Balech (1995) described the species Alexandrium sp. II from warm waters of Mexico (in the Pacific Ocean, in the state of Jalisco), which is morphologically similar to $A$. catenella and A. fundyense, and forms chains of between 2 and 6 cells. However, the size reported for this organism is larger than that from the Mediterranean organism. Mediterranean A. catenella was identified in this study based on cell morphology and the thecal plate pattern. In addition, Avila et al. (1999) claimed that the toxin profile was typical for $A$. catenella and that it cannot be confused with other dinoflagellate PSP producers from the Mediterranean. The blooms reported here extend the range of temperatures in which this organism has been observed to bloom. The well-defined seasonality during the summer months in Catalan waters makes it clear that at water temperatures over $20^{\circ} \mathrm{C}$ this species not only survives, but also blooms. A. catenella is, thus, a cosmopolitan species that can live in a wide range of temperatures from cold to warm waters. It is tempting to suggest that the warm Alexandrium sp. II of Balech (1995) may be related to $A$. catenella from Mediterranean and Japanese waters.
The historical absence of Alexandrium catenella in the samples taken for monitoring prior to the summer of 1996 (Fig. 3) suggests that during recent years the dinoflagellate is expanding its geographical distribution along the Catalan coast. This is of importance because its toxicity may cause considerable economic damage to aquaculture and the shellfish harvest. Three possible explanations have been suggested for the world-wide increase of HABs: (1) an increase in the research of phytoplankton and resulting gains in knowledge, (2) the stimulation of phytoplankton growth due to anthropogenic effects leading to eutrophication, and (3) an increase in the geographical dispersion due to the transport of resting cysts in ballast water, or due to the movement of mollusc stocks from one area to another.

We do not think that in our study area Alexandrium catenella was missed in the past. Despite the long tradition of phytoplankton studies, the species was only observed once in very low concentrations (Margalef \& Estrada 1987). Thus, we can conclude that the abundance and distribution along the NW Mediterranean have increased.

The second explanation suggested for the worldwide increase of HABs is stimulation due to the eutrophication effect of anthropogenic activities. Coastal waters all over the world are, in general, sufficiently rich in nutrients, and the coast studied here is no exception. Imbalance in the ratios between nitrogen, phosphorus and silicate has been reported as a cause of changes in phytoplankton communities (Justic et al. 1995). The general shift in nutrient ratios toward silicate limitation, as suggested previously, could favour growth of dinoflagellates over diatoms. 
Table 1. Concentrations of major inorganic nutrients $(\mu M)$ and their average atomic ratios in the near-shore Catalan surface waters in summer (June to September). The area is divided into 3 regions (North; the area affected by Alexandrium catenella; South). Frequency of single nutrient limitation (\% of occurrence), stoichiometric (Stoich) and probable (Prob), has been calculated as in Justic et al. (1995) (criteria, see footnotes). Range is given from the 25th to 75 th quartile. Data come from an extensive environmental monitoring programme (61 beaches and 11 harbours sampled monthly during 3 and 2 annual cycles respectively)

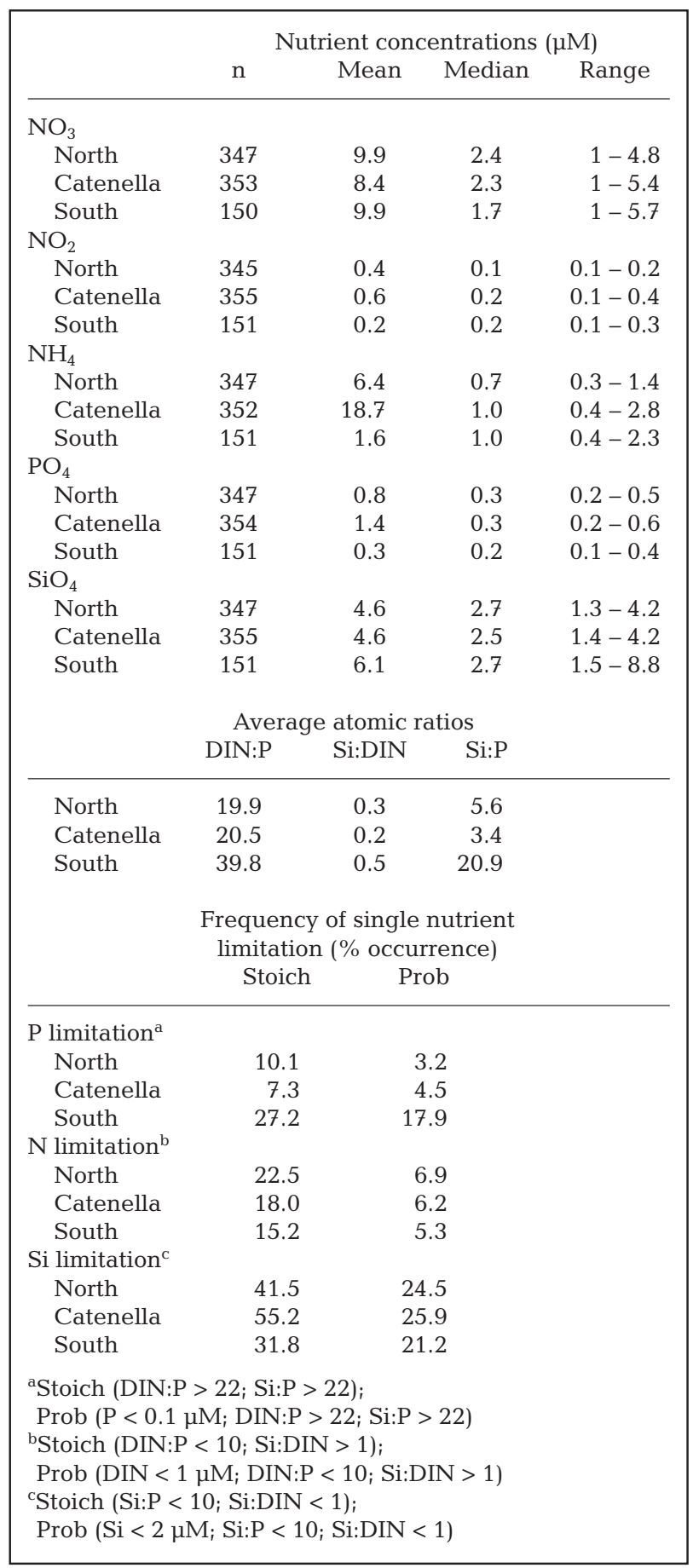

The third explanation is recent importation of the species to the area. The non-indigenous dispersion of species in marine coastal waters in the ballast water of cargo vessels was first suggested 90 yr ago (Ostenfeld 1908), but reports on the occurrence of dinoflagellate cysts in ballast water also appear much later (Hallegraeff et al. 1990, 1991, Hallegraeff \& Bolch 1992). Since then, the number of studies dealing with this topic has increased, with major attention to the dispersion of potentially toxic phytoplankton, because of their economic influence. For some regions evidence has already been presented of the introduction of species through ballast water (Scholin 1996, Hallegraeff 1998). Also, the transfer of mollusc stocks from one area to another has been implicated in the dispersion of dinoflagellates (Laabir \& Gentien 1999). Alexandrium catenella is one of the species now believed to have been introduced into Australian waters from Japan in the last 10 to $20 \mathrm{yr}$ through ballast water transportation (Scholin \& Anderson 1996, Hallegraeff 1998). In Hong Kong waters, there was no record of this species until the 1980s, and its form of introduction is still under discussion; Ho (1998) claimed that oceanic currents introduced it from Japan. In the Mediterranean, hidden flora cannot be disregarded as an inoculum of the blooms because $A$. catenella was previously detected in Mediterranean oceanic waters (Margalef \& Estrada 1987). However, the fact that the bloom was first observed in Barcelona harbour, an important commercial harbour in the area, points to ballast water as the source of introduction. A total of $17251 \mathrm{~m}^{3}$ of water is ballasted monthly into the Barcelona harbour area (inside the harbour or within 12 nautical miles). Other than Mediterranean waters $(60 \%)$, a large amount of ballasted water entering the harbour $(21 \%)$ comes from the South and North Atlantic Ocean (African and European coasts) and the North Pacific Ocean (Asian coast) (Autoritat Portuària de Barcelona 2000). Considering that $85 \%$ to $95 \%$ of the ballast waters brought into Barcelona harbour have been transported for $<30 \mathrm{~d}$, there is a high probability that viable cysts could arrive. The possible origin of Mediterranean A. catenella will not be discussed further in this study. Future work will focus on this topic. What we propose here is a fourth possibility to explain the $A$. catenella expansion along the Catalan coast. This aspect has hardly been considered, but may be the most relevant in calm, tideless seas and on heavily populated coasts such as those found on the Mediterranean. Recreational use of the coast generates the construction of harbours or enclosed beaches. This, together with the mild effect of tides in the area, generates semi-enclosed bodies of water. Thus, these confined environments have high water residence times of about $20 \mathrm{~d}$, low turbulence and low advection in comparison with non-confined waters. Since low turbu- 
lence (Margalef 1978, Margalef et al. 1979) favours dinoflagellate proliferation and some specific properties of these organisms (pattern swimming, auto-regulated aggregation and toxicity) are known to reduce grazing (Fiedler 1982, Bagøien et al. 1996, Smayda 1997, Teegarden 1999), these organisms having low growth rates may bloom in such confined areas. Thus, A. catenella, which has a maximum specific growth rate of 0.47 to $0.55 \mathrm{~d}^{-1}$ in culture under nutrient-saturated conditions (Matsuda et al. 1999), can attain high cell densities (up

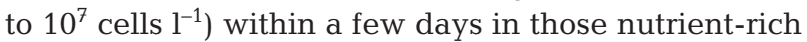
areas and is also favoured by behavioural strategies (swimming, active vertical migrations and aggregation) (Garcés et al. 2000).

Much evidence points to a connection between the Alexandrium catenella blooms and the dynamics of benthic resting cysts: (1) the simultaneous A. catenella appearance along the coast, not only in the confined areas where it blooms, but in a much larger area, as exemplified by the widespread summer blooms of 1998 and 1999; (2) the observation of hypnozygotes enveloped in a matrix of mucilage at Castelldefels beach, coinciding with a decline in the planktonic population in July 1999 (data not shown); (3) the yearly reoccurrence of $A$. catenella at an increasing number of fixed stations (harbours) (Fig. 3). This latter fact could be due to cyst deposition in previously unaffected areas which provided the species with widely dispersed inoculum sites for future blooms, as has been suggested for other areas (Anderson \& Wall 1978). Harbours are considered to be ideal environments for cysts to settle and remain in seedbeds until environmental conditions induce their germination (Anderson et al. 1987). The active growth rate of a small germinating population amplified by the organism's behaviour, the reduction of grazing and the favourable physical factors noted above could cause the blooms in harbours.

The different confined blooms found in the study area are probably part of 1 single, widespread and amplified bloom within the harbours, due to specific favourable environmental conditions in confined waters, as was proposed for Alexandrium taylori (Garcés et al. 1999). Maximum cell concentration at harbour stations during summer 1998 and 1999 were coincident with maximum cell concentration at non-confined and open-water stations (detailed in Vila et al. in press), showing a connection between confined, nonconfined and open, near-shore blooms.

The problems associated with Alexandrium catenella blooms in Mediterranean coastal waters have increased in the past few years. We do not want to imply that anthropogenic influences along the coastlines have changed in the last $5 \mathrm{yr}$, coinciding with the bloom of $A$. catenella. However, we argue that the Catalan coast has the right conditions for dinoflagel- late colonisation and later expansion, as well as for colonisation by new species. So, if a new species arrives, the increased number of confined environments will facilitate colonisation and establishment by the organism. The wide geographical and temporal distribution of $A$. catenella in Catalonia during the last 4 summers indicates that it is currently well established in the region, and is a significant contributor to the summer phytoplankton community in many confined areas and, sometimes, in non-confined waters. Our results suggest that in the future the species might further expand its geographical extension in the Mediterranean Sea. However, this possibility has to be considered with caution. Recently, A. minutum was reported to exhibit a cyclic occurrence pattern, i.e. occurrence increased, stabilised and decreased (Ismael \& Halim 2000) in the eastern harbour of Alexandria, the type locality of the species. This dinoflagellate had been a recurrent summer phenomenon for 40 yr. However, after 1994 it disappeared, and daily observations in the summer of 1999 showed A. minutum to have been replaced by a community of other potentially harmful species. In that sense HABs can be compared to the success and subsequent replacement of invasive plagues in agricultural land.

Acknowledgements. The authors thank J. Riba for his cooperation and his efforts in facilitating the field programme. We thank T. Smayda and S. Fraga for their valuable comments on the manuscript, $K$. Matsuoka for information about $A$. catenella blooms in Japanese waters and the personnel of Servei de Medi Ambient in Barcelona harbour for the vessel ballast-water information. The comments and suggestions of anonymous reviewers also improved the manuscript. We also thank J. M. Gasol for critical reading of the manuscript and English corrections. R. Ventosa performed the nutrient analysis. Financial support was provided by ACA (Department de Medi Ambient, Generalitat de Catalunya) and CSIC though the contract 'Plà de vigilància de fitoplàncton nociu i tòxic a la Costa Catalana'.

\section{LITERATURE CITED}

Anderson DM (1997) Turning back the harmful red tide. Nature 388:513

Anderson DM, Wall D (1978) Potential importance of benthic cysts of Gonyaulax tamarensis and G. excavata in initiating toxic dinoflagellate blooms. J Phycol 14(2):224-234

Anderson DM, Taylor CD, Armbrust EV (1987) The effects of darkness and anaerobiosis on dinoflagellate cyst germination. Limnol Oceanogr 32(2):340-351

Anderson DM, Sullivan JJ, Reguera B (1989) Paralytic shellfish poisoning in Northwest Spain: the toxicity of the dinoflagellate Gymnodinium catenatum. Toxicon 27(6): 665-674

AOAC (Association of Offical Analytic Chemists) (1980) Standard mouse bioassay for paralytic shellfish toxins. In: Horwitz W (ed) Official methods of analysis, 13th edn. AOAC, Washington, DC, p 298-299

Autoritat Portuària de Barcelona (2000) Estudio de la prob- 
lemática de la contaminación por aguas de lastre en el puerto de Barcelona (resultados preliminares de la primera fase). Autoritat Portuària (Servei Medi Ambient), Barcelona

Avila E, Fraga S, Franco J (1999) Perfil de toxinas de Alexandrium catenella en el Mediterráneo. In: Marquez I (ed) VI Reunión Ibérica sobre Fitoplancton Tóxico y Biotoxinas 55/00. Viceconsejería, Sevilla, p 227-230

Bagøien E, Miranda A, Reguera B, Franco JM (1996) Effects of two paralytic shellfish toxin producing dinoflagellates on the pelagic copepod Euterpina acutifrons. Mar Biol 126: 361-369

Balech E (1995) The genus Alexandrium Halim (Dinoflagellata). Special publication, Sherkin Island Marine Station, Cork

Delgado M, Matamoros E, Vila M, Garcés E, Camp J (1998) Seguimiento del fitoplancton nocivo en la Costa Catalana en los años 1995-96. In: Vieites JM, Leira F (eds) V Reunión Ibérica de Fitoplancton Tóxico y Biotoxinas. ANFACO-CECOPESCA, Vigo, p 25-35

Delgado M, Santmartí M, Vila M, Garcés E, Camp J (1999) Seguimiento del fitoplancton tóxico en las bahias del Delta del Ebro en los años 1997-1998. In: Marquez I (ed) VI Reunión Ibérica sobre Fitoplancton Tóxico y Biotoxinas 55/00. Viceconsejería, Sevilla, p 51-58

Fiedler PC (1982) Zooplankton avoidance and reduced grazing responses to Gymnodinium splendens (Dinophyceae). Limnol Oceanogr 27:(5)961-965

Font J, Salat J, Tintoré J (1988) Permanent features of the circulation in the Catalan sea. In: Minas HJ, Nival P (eds) Océanographie pélagique Méditerranéenne. Oceanol Acta (Spec) 9:51-57

Fritz L, Triemer RE (1985) A rapid simple technique utilizing calcofluor white M2R for the visualization of dinoflagellate thecal plates. J Phycol 21:662-664

Garcés E, Masó M, Camp J (1999) A recurrent and localized dinoflagellate bloom in Mediterranean beach. J Plankton Res 21(12):2373-2391

Garcés E, Masó M, Vila M, Camp J (2000) Harmful algae events in the Mediterranean: are they increasing? HAN 20:10-11

Gomis C, Alcober J, Bernabeu A (1996) Seguimiento de las poblaciones fitoplanctónicas en las bateas mejilloneras del puerto de Valencia, 1991-1994. In: Matamoros E, Delgado M (eds) IV Reunión Ibérica de Fitoplancton Tóxico y Biotoxinas. Generalitat de Catalunya. Departament d'Agricultura, Ramaderia i Pesca, St. Carles de la Ràpita (Tarragona), p 29-38

Grasshoff K, Ehrhardt M, Kremling K (1983) Methods of sea water analysis. Verlag Chemie, Weinheim

Hallegraeff GM (1993) A review of harmful algal blooms and their apparent global increase. Phycologia 32:79-99

Hallegraeff GM (1998) Transport of toxic dinoflagellates via ships' ballast water: bioeconomic risk assessment and efficacy of possible ballast water management strategies. Mar Ecol Prog Ser 168:297-309

Hallegraeff GM, Bolch CJ (1992) Transport of diatoms and dinoflagellates resting spores in ships' ballast water: implications for plankton biogeography and aquaculture. J Plankton Res 14(8):1067-1084

Hallegraeff GM, Bolch CJ, Bryan J, Koerbin B (1990) Microalgal spores in ships' ballast water: a danger to aquaculture. In: Graneli E (ed) Toxic marine phytoplankton. Elsevier, New York, p 475-480

Hallegraeff GM, Bolch CJ, Blackburn SI, Oshima Y (1991) Species of the toxigenic dinoflagellate genus Alexandrium in south-eastern Australian waters. Bot Mar 34:575-587
Ho KC (1998) Variations in the PSP contents of shellfish in Hong Kong and the eastern coast of South China Sea. J Shellfish Res 17(5):1657-1660

Ismael AA, Halim Y (2000) Occurrence and succession of potentially harmful phytoplankton species in the eastern harbour of Alexandria. In: Abstract Book, 9th International Conference on Harmful Algal Blooms. Hobart, Tasmania, p 24 (abstract)

Justic D, Rabalais NN, Turner RE, Dortch Q (1995) Changes in nutrient structure of river-dominated coastal waters: stoichiometric nutrient balance and its consequences. Estuar Coast Shelf Sci 40:339-356

Laabir M, Gentien P (1999) Survival of toxic dinoflagellates after gut passage in the Pacific oyster Crassostrea gigas Thunburg. J Shellfish Res 18(1):217-222

Margalef R (1978) Life-forms of phytoplankton as survival alternatives in an unstable environment. Oceanol Acta 1(4):493-509

Margalef R, Estrada M (1987) Synoptic distribution of summer microplankton (algae and protozoa) across the principal front in the western Mediterranean. Investig Pesq 51: $121-140$

Margalef R, Estrada M, Blasco D (1979) Functional morphology of organisms involved in red tides, as adapted to decaying turbulence. In: Taylor DL, Seliger HH (eds) Toxic dinoflagellate blooms. Elsevier, Amsterdam, p 89-94

Masó M, Duarte C (1989) The spatial and temporal structure of hydrographic and phytoplankton biomass heterogeneity along the Catalan coast (NW Mediterranean). J Mar Res 47:813-827

Masó M, Tintoré J (1991) Variability of the shelf water off NE Spanish coast. J Mar Syst 1:441-450

Matsuda A, Nishijima T, Fukami K (1999) Effects of nitrogenous and phosphorus nutrients on the growth of toxic dinoflagellate Alexandrium catenella. Nippon Suisan Gakkaishi 65(5):847-855

Ostenfeld CJ (1908) On the immigration of Biddulphia sinensis Grev. and its occurrence in the North Sea during 1903-1907. Medd Kommn Havunders (Ser Plankton) 1:1-44

Scholin CA (1996) Morphological, genetic and biogeographic relationships of toxic dinoflagellates Alexandrium tamarense, A. catenella and A. fundyense. In: Anderson DA, Cembella AD, Hallegraeff GM (eds) Physiological ecology of harmful algal blooms. Springer-Verlag, Heidelberg, p 13-27

Scholin CA, Anderson DM (1996) LSU rDNA-based assays for discriminating species and strains of Alexandrium (Dinophyceae). J Phycol 32:1022-1035

Smayda TJ (1990) Novel and nuisance phytoplankton blooms in the sea: evidence for a global epidemic. In: Graneli E, Sundström B, Edler L, Anderson DM (eds) Toxic marine phytoplankton. Elsevier, New York, p 29-40

Smayda TJ (1997) Harmful algal blooms: their ecophysiology and general relevance to phytoplankton blooms in the sea. Limnol Oceanogr 42(5, Part 2):1137-1153

Steidinger KA, Tangen K (1997) Dinoflagellates. In: Tomas CR (ed) Identifying marine phytoplankton. Academic Press, St. Petersburg, FL, p 387-584

Takeuchi T (1994) The Ecology of Alexandrium catenella, a toxic red tide dinoflagellate in Tanabe Bay, Wakayama Prefecture. Bulletin of Wakayama Prefecture Fisheries Experimental Station Special, No. 2:88pp

Takeuchi T, Kokubo T, Fukuyo Y (1990) Distribution of vegetative cells and cysts of Alexandrium catenella (Dinophyceae) in Tanabe Bay. Bull Plankton Soc Jpn 37(2): 157-165 
Taylor FJR (1984) Toxic dinoflagellates: taxonomic and biogeographic aspects with emphasis on Protogonyaulax. In: Ragelis EP (ed) Seafood toxins. American Chemical Society, Washington DC, p 77-97

Taylor FJR, Haigh R, Sutherland TF (1994) Phytoplankton ecology of Sechelt Inlet, a fjord system on the British Columbia coast. II. Potentially harmful species. Mar Ecol Prog Ser 103:151-164

Teegarden GJ (1999) Copepod grazing selection and particle discrimination on the basis of PSP toxin content. Mar Ecol Prog Ser 181:163-176

Throndsen J (1995) Estimating cell numbers. In: Hallegraeff

Editorial responsibility: Otto Kinne (Editor),

Oldendorf/Luhe, Germany
GM, Anderson DM, Cembella AD (ed) Manual on harmful marine microalgae. IOC manuals and guides No. 33. UNESCO, Paris, p 63-80

Vila M, Camp J, Garcés E, Masó M, Delgado M (2001a) High resolution spatio-temporal detection of potentially harmful dinoflagellates in confined waters in the NW Mediterranean. J Plankton Res 23(5):497-514

Vila M, Delgado M, Camp J (2001b) First detection of widespread toxic events caused by Alexandrium catenella in the Mediterranean Sea. In: Hallegraeff GM, Blackburn SI, Bolch CJ, Lewis RJ (eds) Harmful algal blooms 2000. Proc. 9th Int Conf Harmful Algal Blooms. IOC, Paris, p 8-11

Submitted: June 2, 2000; Accepted: January 15, 2001

Proofs received from author(s): October 17, 2001 